Karadeniz Uluslararası Bilimsel Dergi

Volume: 51, Autumn-2021, p. (220-233)

ISSN: 1308-6200 DOI Number: https://doi.org/10.17498/kdeniz.973900

Research Article

Received: July 23, 2021 | Accepted: Sep 20, 2021

This article has been checked for plagiarism.

\title{
EY, DÜNYE EY ROMANINDA KAZAKLARDAKİ LAKAP TAKMA, İSIM VERME ÜZERIINE BİR İNCELEME
}

\author{
AN INVESTIGATION ON NAMING AND NICKNAMING OF KAZAKH IN \\ THE NOVEL "EY, DUNYA EY"
}

\section{ИССЛЕДОВАНИЕ НАЗВАНИЯ КАЗАХСКОГО ИМЕНОВАНИЯ И ПРОЗВИЩ В РОМАНЕ «ЕЙ, ДУНИЕ ЕЙ»}

\author{
Hikmet KORAȘ* \\ Gulshat SHAIKENOVA**
}

Öz

İsim verme ve lakap takma bütün toplumlar ve kültürlerde insanın yaratılışı ile ortaya çıkmıştır. İsimler, toplumdan toplama değişmekle birlikte genellikle kişilerin birinci derecede yakınları tarafindan verilirken lakaplar kişilere arkadaşları veya çevresi tarafindan verilir. Bu sonradan isimlendirme, bir taraftan kişinin karakterini, toplumdaki konumunu, yaptığı işi, çevresiyle iliş̧kisini, etnik kökenini yansıtırken diğer taraftan lakabı verenlerin de kişiye bakışını, ona verdiği değeri, toplum içindeki gördüğü konumu veya görmek istediği konumu ile bu çevrenin sosyal ve kültürel durumu gibi özellikleri de yansıtır. Bazı isimler ve lakaplar insanları ve toplumu yönlendirmek amacıyla konmuştur, bazıları ise yaptığı kötü bir iş ve yanlıştan dolayı yergi amacı taşır. Bazıları tarihi özellikler taşır ve hem kişiye hem çevresine unutulmaması gereken tarihe veya tarihi şahsiyetlere vurgu yapar, bazıları sadece geleneğin gereği konmuştur ama altından bir milletin miti çıkar. Bu isim ve lakapların özgün şeklinde bulunan veya sadece kullanımda eklenen ekler de dil incelemesinde önemlidir. Koyan kişinin isim koyduğu ve lakap taktığı kişiye olan yakınlığı, bakışı, verdiği değer sezilir. Bazılarında toplumun başka toplumlarla ilişkisi, ilişkinin yönü ve derecesi görülür. Toplumların aynası olan edebi eserde ise durum aynı olmakla birlikte biraz farklılık arz eder. Edebi eserlerdeki kişilerin lakapları, bir taraftan bahsettiğimiz özellikleri yansıtırken diğer taraftan yazarın dönem, kişiler, kişilerin edebi eserdeki diğer kişilerle ilişkisini hatta yazarın siyasi, sosyal ve edebi bakışını da yansıtır. Bu gerçekler dikkate alınarak Beksultan Nurjekeulı’nın “Ey, Dünya Ey!” romanında kullanılan lakaplar ve isimler ele alınmış, lakap

\footnotetext{
* ORCID: 0000-0001-7045-2510 Niğde Ömer Halisdemir Üniversitesi Fen-Edebiyat Fakültesi Çağdaş Türk Lehçeleri ve Edebiyatları Bölümü/Türk Dünyası Araştırmaları Merkezi Müdürü, hikmetkoras@gmail.com

** ORCID: 0000-0002-9663-1565 Niğde Ömer Halis Demir Üniversitesi Sosyal Bilimler Enstitüsü, gulshat84@mail.ru
} 


\section{Ey, Dünye Ey Romanında Kazaklardaki Lakap Takma, İsim Verme Üzerine...}

ve isimler dışında bu konuyla ilişkili olarak kişilerin yakınlarının isimlerini kullanırken yaptıkları tasarruf ve değiştirmeler de incelenmiştir.

Anahtar kelimeler: Lakap takma, isimlendirme, isim koyma geleneği, 1916 Kazak Katliamı, göç.

\section{ABSTRACT}

Naming and nicknames emerged with the creation of man in all societies and cultures. Generally, names are given by the first degree relatives of the people and it's varying from society to the society. Nicknames are given to the people by their friends or their environment. This subsequent naming on the one hand, reflects the person's character, position in society, his job, his relationship with his environment, his ethnic origin, and on the other hand, it reflects features such as the viewpoint of those who give the nickname, the value he gives to him, the position he sees in society or the position he wants to see, and the social and cultural situation of this environment. Some names and nicknames are meant to guide people and society; moreover, some of them are satirical for a bad deed and wrongdoing. Some of them have historical features and emphasize both the person and his environment and on the history or historical figures that should not be forgotten. Some of them are just the necessity of the tradition, but the myth of a nation emerges from it. The appendices that are in the original form of these names and nicknames are also important in language analysis. The closeness, look and value of the person named and nicknamed by the person can be perceived. Besides these, the relationship of the society with other societies, the direction and degree of the relationship can be seen. In the literary work, which is considered the mirror of societies, the situation is the same, but it differs a little. The nicknames of literary works on the one hand, reflect the characteristics we have mentioned and on the other hand, they reflect the relationship of the author with the other people in the literary work, and even the political, social and literary perspective of the author. Considering these facts, Beksultan Nurjekeuli's "Ey, Dunya Ey" the nicknames and names used in the novel were discussed, and the savings and changes made by individuals using the names of their relatives in relation to this subject were also examined.

Keywords: Nicknaming, naming, naming tradition, 1916 Kazakh Massacre, immigration

\section{АННОТАЦИЯ}

Именование и прозвища появились с сотворением человека во всех обществах и культурах. Как правило, имена даются родственниками людей первой степени родства, и это варьируется от общества к обществу. Прозвищу людям дают их друзья или их окружение. Такое именование, с одной стороны, отражает характер человека, положение в обществе, работу, отношения с окружающей средой, этническое происхождение, а с другой стороны, оно отражает такие особенности, как точка зрения тех, кто дает прозвище, ценность, которую он придает ему, положение, которое он видит в обществе или положение, которое он хочет видеть, а также социальная и культурная ситуация в этой среде. Некоторые имена и прозвища предназначены для руководства людьми и обществом, более того, некоторые из них являются сатирическими над плохими поступками и проступками. Некоторые из них имеют исторические особенности и делают упор как на человека, так и на его окружение, а также на историю или исторические личности, о которых нельзя забывать. Приложения в оригинальной форме этих имен и псевдонимов также важны при анализе языка. Можно ощутить близость, внешний вид и ценность человека, которого назвал человек. Помимо этого, можно увидеть отношения общества с другими обществами, направление и степень взаимоотношений. В литературном творчестве, 


\section{Hikmet KORAŞ - Gulshat SHAIKENOVA}

которое считается зеркалом обществ, ситуация такая же, но немного отличается. Прозвища литературных произведений, с одной стороны, отражают характеристики, которые мы упомянули, а с другой стороны, они отражают отношения автора с другими людьми в литературном произведении и даже политическую, социальную и литературную перспективу автора. Принимая во внимание эти факты, были обсуждены прозвища и имена, использованные в романе Бексултана Нуржекеевича «Эй, Дуня Эй», а также были изучены сбережения и изменения, сделанные людьми, использующими имена своих родственников в отношении этой темы.

Ключевые слова: прозвище, именование, традиция именования, казахская резня 1916 года, иммиграция.

\section{Giriş}

Kazaklar, uzun yıllar Rus hâkimiyetinde yaşamış, 20. Yüzyılın başında kimliklerinin farkına varmış ve bu kimliği yaşatma mücadelesi vermeye başlamışlardır. Bu mücadele 1916 yılında Çarlık Rusya’sının fiili bir katliamına dönüşmüştür. Binlerce kişi bulunduğu yeri terk ederek doğu Türkistan'a doğru kaçar. Katliamdan kurtulanların çoğu bu göç sırasında ölür. Her ne kadar 1916 yılında gerçekleşen Bolşevik ihtilaliyle Kazaklar 1992 yılına kadar susmak zorunda kalsalar da bağımsızlıklarını kazandıktan sonra milli kimlik inşasında önemli bir eşik olan bu katliamı unutmamışlardır. Romanda yaşanan bu elim olayın yüzüncü yılına ithafen yazılmış ve devlet ödülü almıştır. Yazar bu romanla sadece tarihi bir olayı gündeme getirmek ve diri tutmak ötesinde tarihi günümüze çağırmak ve tarihle geleceği inşa etmek için bütün unsurları kullanmıştır. Cannerton, canlandırma ve anımsamayı geçmişi bu güne çağırmanın iki yolu olarak belirtir (Çakır 2018: 33). Bunun yanında isim vermede, kişinin şahsiyetinin aldığ1 isme göre şekilleneceği inancı da isim koymada etkilidir (Türktaş 2019: 35-36). Bu bağlamda romanın kurgusu canlandırma, romandaki diğer unsurlar, özellikle isimler, lakaplar ve bunların pratikte kullanılışı geçmişi çağırma, geleceği inşa etme gayretleridir.

Kazak Türkçesi dâhil olmak üzere Türkçenin çoğu lehçelerinde lakap sözcüğ̈̈ hemen hemen aynı anlamda kullanılmaktadır (Ercilasun vd. 1991: 534-35). Bu gün ayrı birer yazı diline sahip olsalar da ad koyma ve lakap takma geleneği bütün Türklerde ortak bir değerdir (Gülensoy 1994: 6). Lakapların ilk örnekleri de Türk destanlarında kimi zaman aşağılayıcı, kimi zaman özel bir ayrıcalık katıcı özellikleriyle görülür (Erol Çalışkan 2016: 105). Lakap, insanın vücut yapısına, dış görünüşüne, psikolojik özelliğine ya da uğraştığı işine göre verilir (Januzakov 1971: 77). Edebi bir eserde kullanılan lakaplar ise bir taraftan bu değerlerin yansıması diğer taraftan da edebi eserin sahibinin eserdeki olaylara, kişilere, topluma bakışı ile aynı zamanda kendi sosyal, siyasi görüşlerini, yorumunu, bakışını yansıtır.

İnsanların kendilerini ve diğerlerini adlandırma eğilimleri, günümüzde adbilim (onomastik) alanını, onun içinde kişi adları (antroponim), yer adları (toponimi) ve coğrafya adları (hidronimi) olarak üç gruba ayrılan bilim alanlarını ortaya çıkarmıştır (Aksan 2015: 100, Kayasandık 2019: 59). Dünya dillerinde ad verme geleneği, milletlerin inanışı, kültürü ile sıkı bağlantılıdır. Onun dilbilimi açısından incelenmesi dilin ve kültürün önemli unsurlarını ortaya çıkarır. Toplum dilbilimi açısından bakıldığında da lakap takma, toplum içindeki ilişkileri izah 


\section{Ey, Dünye Ey Romanında Kazaklardaki Lakap Takma, İsim Verme Üzerine...}

etmemize yardımcı olur. Bir kişinin doğuştan sahiplendiği ismine belli bir yaştan sonra ek olarak başka bir ismin verilmesi, o şahsın mizacını ve toplumdaki yerini göstermektedir (Türktaş, 2019: 36). Bu isimlendirmeleri zaman ve mekân içerisinde analiz ettiğimizde, inceleme konusu olan toplumun yaşam düzenini, kalıp yargılarını, düşünce tarzını, insanlar arası ve toplumsal ilişkilerini anlamak daha kolay bir hale gelecektir.

Toplumun aynası olan edebi eserlerdeki lakap takma veya isimlendirme de aynı nitelikleri taşımakla birlikte, ilaveten yazarın şahsi görüşlerini de yansıtır. Edebi eserde kullanılan lakaplar, bir taraftan toplumsal değerleri ve yazarın topluma, olaylara, kişilere bakışını yansıtırken diğer taraftan yazarın okuyucuya vermek istediği mesajların da bir parçasını oluşturur. Bunlardan bazıları kişilerin inancı, uyruğu, toplumdaki yeri, yaşı, mesleği, çevresi, sahip olduğu diğer toplumsal değerlerdir (Aksan 2015: 95).

Lakap, bir kişinin veya ailenin taşıdığı addan ayrı olarak, kişi veya ailenin toplumdaki konumu, yaptığı iş, toplumsal ilişkisi veya karakteri ile ilgili olarak başkaları tarafindan takılan sonraki isimdir (Oğuz vd. 2008: 1127). Bazı araştırmacılar lakapların anlam açısından toplum içerisinde iyi karşılandığı takdirde kişi adına dönüşme olasılığı yüksektir (Erol Çalışkan 2016: 105) dese de kişi veya ailelere sonradan takılan pek çok olumsuz ismin de kalıcı olduğu herkesin malumudur. Ancak kötü anlam taşıyan pek çok kelimenin iyi insanlara isim veya lakap olmasıyla anlamının değiştiği de hatırdan çıkarılmamalıdır.

Lakapların yapısı dikkate alındığında, bir kısmının bir kişinin adından bağımsız olarak başka bir isim verilmesi veya mevcut isme ek veya kelime ilavesi yapılarak kullanılması şeklinde iki kullanım görülmektedir. Kişinin ismine ek veya ikinci bir kelime ilave ederek lakap takma veya kullanım da iki farklı şekilde oluşmaktadır. Birincisi, kişinin özgün ismine can, bek gibi unvanlar ve varyantları ile sevgi, şefkat, acıma gibi duyguları ifade eden küçültme ekleri eklemek suretiyle oluşurken, ikincisinde özgün ismin ilk hecesi alınarak veya ismin son hecesi veya hecedeki bazı sesler atılarak kelime ilave edilmekte veya ek getirilmektedir. Elbette bu yapıların bir kısmı ismin özgün şeklini oluştururken bir kısmı sadece kullanımda ortaya çıkan şekillerdir. Mesela roman kahramanının adı Şeyi iken eşi ona Şayken veya Şaykentay diye hitap eder. Yine Şeyi, eşinin adı Tazabek iken ona isminin ilk hecesine ek ilavesiyle Tayken ve daha uzatarak Taykentay diye hitap eder.

Edebi eserlerde yazarın kahraman veya kahramanla ilişkili olan kadroya koyduğu isimler eserin konusu ve türü ile de ilgilidir. Tarihi bir romanda roman kahramanlarının daha çok tarihi olaylarda adı geçen kahramanlardan seçilmesi, kurgu romanlarda genellikle hiç duyulmamış zaman zaman yazarın kendisinin uydurduğu bilimsel gelişme ve hayal ürünü olan isimler olduğu görülür. Nurjekeul, eserdeki birinci derecede kahramanlardan başlamak üzere bütün isimleri Kazak kimliğini oluşturmak temel fikrinden hareketle seçmiştir. Bunlardan bir kısmı tarihidir, bir kısmı Kazak sosyal hayatının ve geleneğin bir parçasıdır. Bolşevikler için kullandığı balşebek yakıştırması, normalde kelimenin telaffuzunun zorluğundan kaynaklanıyor gözükse de insanlara özgürlük vaat edip zulmeden bir rejim için ince bir yergi taşır. İsimlerin ve lakapların kullanılışı diyebileceğimiz özgün ismin 
dışındaki şekiller de hem Kazak sosyal hayatının hem geleneğin günümüze çağrılması ve Kazak kimliği inşasında önemlidir.

Kazak sosyal hayatında kişilere verilen isimler dışında takılan lakapları takan kişi veya kişileri dikkate alarak da değerlendirmek mümkündür. Eşlerin birbirine, annenin çocuklarına, çocukların anne baba ve diğer büyüklerine, akrabaların birbirine hitabındaki isim değişiklikleri veya lakap takmalar da bu şekilde değerlendirilebilir.

\section{Eserde Yazarın Yaptığı İsimlendirmeler}

Elbette bir edebi eserdeki bütün isimler eserin yazarı tarafindan verilmiștir. Ancak yazar bu isimlendirmeleri yaparken içinden çıktığı toplumun bütün değerlerini dikkate alarak yapar, kendisini gizlemeye çalışır. Bunlar lakap değil isimlendirmedir ancak yazarın okuyucuya vermek istediği mesajın da bir parçasıdır. Özellikle tarihi romanlarda isimlendirmeler bu açıdan öne çıkar ve önem kazanır. Tarihi roman olsa da bir diğer önemli husus romandaki olayın konu edildiği dönemdeki kişilerin sosyal statüleri ve toplumsal rollerinin olduğu gibi yansıtılmasıdır. Bu manada bayanların isimlerinde, inceliği, kibarlığı, zarafeti, değerliliği öne çıkaran kelimeler seçilir. Bu tercih toplumun kadına yüklediği sosyal statü, yüklemek istediği rol ve verdiği değeri de ifade eder. Yine erkeklerde yiğitlik, kahramanlık, beceriklilik, ailesi ve mensubu bulunduğu topluma faydalı olma sıfatları ile tarihi şahsiyetlerin isimleri dikkat çeker. Bu isimler de toplumun onlara yüklediği görev, verdiği sosyal statü ile sorumluluğu hatırlatır.

Romanın kadın kahramanı Şeyi, Kazak toplumunun o dönemlerdeki durumunu en iyi yansıtan şahsiyettir. Yazar, bunca olayları yaşayan Şeyi'nin kederini anlatırken bir yandan da tüm Kazak toplumunun kaderini, çektikleri sıkıntıları anlatır. Şeyi’nin anlamı ipeğimsi kumaş demektir (Jayabekova vd. 2011: 308). Şeyi'ye yengesi Jüzik'in Jibek (Nurjekeulı 2016: 20) demesi ve Jibekjan diye hitap etmesi hem adının ipeğe benzeyen kumaş olmasından hem de ipek gibi yumuşak, değerli, aranan, kibar, nazik olduğu mesajını vermek içindir.

Kişi adları ile birlikte söylenen unvanlar ve unvanlarda geçen meslek adları da insan hakkında bilgiler verir. Yazar, romanın erkek kahramanına, Rusların 19. yüzyılda gerçekleştirdiği işgal hareketine Ulu Cüz'ün Alban koluna mensup Kazaklarının Aksakalı Tazabek'in ismini vermiștir (Bacaklı 2019: 254-274). Tarihi bir şahsiyetin roman kahramanlarından birisine ad olarak verilmesi, bu isim verilirken de o ismin kahraman ile bağlantısının kurulmasını, ad verme geleneğinin geçmişi geleceğe taşımak ve kültürel ideolojiyi yaşatmak (Çakır 2018: 32) şeklinde değerlendirmek mümkündür.

Romanda Tazabek ile Şeyi arasında geçen konuşma sırasında Tazabek' in dedelerinden birçok isimden bahsedilmiştir: Tazabek Pusırman balası, Şoqan töregalım ata, Savrık batır, Şaltabay seri, vb. (Nurjekeulı 2016: 18, 19). Bu isimlerle birlikte zikredilen töre, ğalım, batır, seri gibi eski Kazak toplumunda bir unvan olarak kalıplaşan kelimeler, bu şahsiyetlerin saygı gösterilen ve sevilen kişiler olduklarının göstergesidir. Fakat bekler, batırlar ve biylerin neslinden gelen Tazabek'in bu dönemdeki hayatı, onun dedelerininkinden farklıdır. İkisinin 


\section{Ey, Dünye Ey Romanında Kazaklardaki Lakap Takma, İsim Verme Üzerine...}

konuşması ile yazar, Kazakların mevcut durumunu eskiyle kıyaslayarak göstermeye çalışmıştır. Alayda Tazabek atayız el qamın jep orısqa qarsı bolsa, siz qamııızdı jep orısqa quzmet jasap jürsiz ğoy? "Ama Tazabek atan halk1 düşünüp Ruslarla mücadele etmiş, sen ise kendi rahatın için Ruslara hizmet ediyorsun!" (Nurjekeulı 2016: 19).

\section{Eserde Halk Tarafindan Takılan veya Öyle Gösterilen İsimlendirmeler}

Lakaplar genelde halk tarafından verilir. Eğer takılmış lakap insanın tabiatını doğru yansitırsa, değişmeden istikrarlı bir şekilde korunur (Januzak 2007: 79). Kişinin yaşadığı toplum içerisindeki insanların ona saygı gösterdiğini ona verilmiş̧ lakaptan anlamak mümkündür. Mesela, eserde görülen Kanıkey adlı kadının lakabı olan Kökşegir buna iyi bir örnektir. Yazar bu adı, Kökşegir albandardıり koyğan atı "Kökşegir, Albanların verdiği isim" (Nurjekeulı 2016: 110) diye nitelendirir. Kartal, Kazak toplumunda bayrağa sembol olacak kadar önemli bir yere ve kutsiyete sahiptir. Kökşegir, kartalın güçlü olan türlerinden biridir (Kaliyev 2014: 283). Böyle bir lakap, romandaki Kanıkey'in mizacını, bilgeliğini yansıtmaktadır. Kanıkey (Kökşsegir), tarihte yaşamış bir şahıstır. Bu bilgiye M. Avezov'un "Qıylı Zaman" romanı ile ilgili yazılmış malumatlarda aynı boy içinde, aynı ad ve lakabı görebiliriz (Avezov 2016: 246).

Aqsaqal kelimesi Kazaklar arasında değişmeceli olarak bilge, görmüş geçirmiş, tecrübeli anlamlarına gelir ve saygıyla karşılanmaktadır. Halk arasında hürmet göstermeye değer ihtiyara aqsaqal diye hitap edilir: Kojabek aqsaqal (Nurjekeulı 2016: 91), Aqsaqal "yaş1 büyük kimse" (Nurjekeulı 2016: 201).

Romanda belli bir insanın adı olmasa da dikkatleri çeken adlandırmalardan biri Aq patşa'dır. Aq patşa (Nurjekeulı 2016: 35) lakabı, Rus Çarına verilmiştir. Bununla birlikte, sosyalist yaklaşımı savunan Bolşevikler grubunun ismi de ilginç bir şekilde kullanılmıştır. Romanda karakterler bu adı Balşebek diye telaffuz etmektedir. Balşabek < Bolşevik "Bolşevik" (Nurjekeulı 2016: 165); Amansıydar ma? Jalajaştağ qazaqtardı bälşsebek degen birevler qırıp tastaptı degen ras pa? Sonı bilip kel dep, ülkender meni jumsap edi, jüregim davap qalağa kire almadım, dedi. Bälşebek degen eşkimdi körgem joq. "Nasılsınız? Jalanaş’taki Kazaklara 'Bolşevik' diye birilerinin saldırdığı doğru mudur? Onu öğrenmem için büyükler beni göndermişti fakat şehre girmeye bir türlü cesaret edemedim' dedi. 'Bolşevik' adında kimseyi görmedim.” (Nurjekeulı 2016: 170) Örnekte görüldüğü gibi, Kazak toplumu için tanıdık olmayan bir isimdir, fakat bu ismin sirklerde gösteri yapan şebek adıyla özdeşleştirilmesi de toplumun Bolşeviklere bakışını kısmen yansıtır ve bu isimlendirmede ince bir mizah da vardır. Bu isimlendirmeyi sıradan bir telaffuz zorluğu ile izah etmek doğru değildir.

Lakap, insanın vücut yapısına, psikolojik özelliğine ya da uğraştığı işine göre de verilir (Januzakov 1971: 77). İncelediğimiz romanda rastlanan anşi Sopıya (şarkıcı Sofiya) (Nurjekeulı 2016: 18), köpes Vasiliy (tüccar Vasiliy) (Nurjekeulı 2016: 18), Kırğız otaşı (Kırgız cerrah) (Nurjekeulı 2016: 66), orıs hatşı (Rus hatip) (Nurjekeulı 2016: 97) ataman Aleksandrov ya da orls ataman (Elebaş1 Aleksandrov 
ya da Rus elebaşı) (Nurjekeulı 2016: 169), jalpak bet Kalmak (düz suratlı Kalmuk) (Nurjekeulı 2016: 107) ya da dav Kalmak (Dev Kalmuk) (Nurjekeulı 2016: 108) gibi adlandırmalar bahsi geçen kişilerin yaptığı iş veya kişisel özelliklerinden dolayı takılmış lakaplardır. Kırgız otaşı (Kırgız cerrah), orıs hatşı (Rus hatip) örneklerinde kişilerin kendi adları ile ilgili hiç bilgi verilmemiş, fakat onların lakapları, şahısların etnik kökenlerinden hem uğraştığ1 işlerinden haber vermektedir. Ataman Aleksandrov/orıs ataman "Elebaşı Aleksandrov/Rus Elebaşı" (Nurjekeulı 2016: 169), jalpak bet kalmak "Düz suratlı Kalmuk"/dav kalmak "Dev Kalmuk" (Nurjekeulı 2016: 107) örnekleri de buna benzer bir şekilde romanda karşımıza çıkmaktadır.

$\mathrm{Bu}$ örneklerdeki lakapların küçük harflerle yazılması, inceleme sırasında dikkatimizi çekmiştir. Belli bir isim ya da lakap, genel olarak büyük harflerle yazılırken, bu örnekler küçük harflerle yazılmıştır. Bu özelliğinden dolayı onları lakap olarak saymamak yanlışlık olacağı düşünülerek, konu içerisinde yer verilmiştir. Örneklerdeki adlandırmalar sadece belli bir grup tarafından, kişinin özelliklerine göre adlandırılmış olduğu için hem yazar tarafından kişinin kendi ismini bahsetmekten, daha çok kişisel karakterini esas alarak adlandırma dikkat çekici olacağı düşünülerek kullanılmış olduğu tahmin edilebilir.

\section{Kazak Kültüründe geleneğe bağlı isimlendirmenin bir yönü gelinin yakınlarına taktığı lakaplar}

Kazakların ve Kırgızların geleneklerinde gelin, eşinin kardeşlerine kendi adlarıyla hitap etmez (Januzakov 2007: 84). O yüzden gelinin kendisi onlara lakaplar takar ve bunlar çoğu zaman o şahsın kişisel özeliklerini yansitır. Romanda buna örnek, Şeyi'ye yengesi Jüzik'in Jibek (Nurjekeulı 2016: 20) demesi, Şeyi'nin evlendikten sonra eşinin akrabası olan Kenjeğara'ya Jaqsibala (Nurjekeulı 2016: 240) demesidir. Tazabek'in annesi Kalişa da eşinin abisi olan Adilbek'i Biağa (Nurjekeulı 2016: 87) diye adlandırır. Bunu, olay örgüleri ve karakterlerin

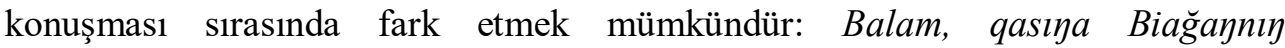
Kenjeğarasın qosıp alsayşı "Oğlum, Beyabinin oğlu Kenjeğara'yı yanına alsaydın" (Nurjekeulı 2016: 87); Kalişa'nın Adilbek'ten Biağa diye bahsetmesi adlandırmadan ziyade adını kullanmadan akrabalık ismiyle hitap etmesidir.

$\mathrm{Bu}$ adlandirmalar Kazaklar arasında tabu olarak kabul edilmekte hala yaşatılmaktadır (Januzakov 1971: 221). Buna ek olarak, aile büyüklerinin, özellikle erkeklerin, gelinlere kendi adıyla hitap etmediklerini de romanda fark etmekteyiz: Kelin, sabır q11! dedi Qojabek. "Gelin, sabırlı ol! dedi Kojabek” (Nurjekeulı 2016: 135), Aa, quday, kelinimniy qadamın quttı qula gör! "Allah'ım gelinimi hayırlı et!”.

\section{İsimlendirmede Kullanılan Ekler ve Diğer Unsurlar}

Bütün Türk lehçelerinde olduğu gibi, Kazak Türkçesinde de kişi adlarına belli ekleri ekleyerek farklı anlamlar katmak mümkündür. B.Nurjekeulı'nın "Ey, Dünye Ey" romanında bunun örneklerini görebiliyoruz. Yazarın kahramanlarına isim vermesi, ya da kahramanların kendi aralarında birbirine isim verdirtmesi gibi olaylar, romanda yer alan toplumun yapısını, zaman içerisinde nasıl şekillendiğini 


\section{Ey, Dünye Ey Romanında Kazaklardaki Lakap Takma, İsim Verme Üzerine...}

daha iyi anlamamıza yardım eder. Romanda anlatılan olayın Kazak tarihinde yaşanmış olması ve karakterlerin tarihî gerçekle olan uyumu, kişi adları incelemesinde önemli noktaları önümüze çıkarmaktadır.

Romanda kullanılan kişi adlarını yapı olarak kabaca basit, türemiş ve birleşik şeklinde değerlendirmek mümkündür. Yine yapı olarak türemiş ve birleşik durumdaki isimleri özgün yapısı böyle olanlar ve kullanım sırasında bu şekli alanlar şeklinde de ikiye ayırmak gerekir. Onlardan çoğu $+(e) k e,+K A n,+s$, +jan,+ tay, $+b e k,+b a y$ ek ve kelimelerinin eklenmesiyle yapılmıştır. Sayılı bir şekilde ${ }_{{ }_{s}} A K$, $+k e s ̧$ eklerinin de kullanıldığını görebiliriz.

${ }_{+} A K A K$ eki ile yapılan tek bir hitabet şekli karşımıza çıkmaktadır. Tazabek, eşi Şeyi'yi şımartarak kelinşegim (Nurjekeulı 2016: 82) diye hitap ettiğindeki kelinşek sözcügü, kelin (gelin) ismine + şek (+CAk) ekinin gelmesi sonucunda oluşmuştur. Kazak Türkçesinde +şAK eki, eklendiği kelimeye küçültme, şımartma, sevgi, şefkat anlamlarını katar (Iskakov 160: 1991). Türkiye Türkçesinde +Cak: +CA eşitlik, benzerlik, karşılaştırma eki ile +ok pekiştirme eklerinin kaynaşmasından ortaya çıkan ek, eklendiği kelimeye küçültme, sevgi, tahsis anlamlarını kazandırır (Korkmaz 2019: 124). Korkmaz, eki bu şekilde açılamıştır. Kazak Türkçesindeki +şAK küçültme ekinin ise, çocuklar anlamını taşıyan, sadece bala-şağa sözcügünde korunan şăga kelimesinden geldiği düşüncesi vardır (İbatov 1986: 87). Bu ekin Eski Türkçede + çIK, +çUK şeklinde kullanılmış olduğu da belirtilmiştir. Rus âlimleri de ekin kökenini zaman anlamını veren şak (çağ) kelimesi ile ilişkilendirmiştir (İbatov 1986: 87).

$+k e s ̧$ eki, $+k e$ küçültme ekinin (Kononov 1969: 81-88) üstüne $+c ̧$ küçültme ekinin gelmesi ile oluşmuştur. Kononov her ne kadar bikeç kelimesini bik+eş şeklinde ayırmışsa (Kononov 1969: 81-88) da aslında kelimenin kullanımı dikkate alındığında $b i+k e s ̧ s ̧$ şlinde ayrılması daha doğru olur. Ek, kelime sonundaki $+c ̧$ ünsüzünün/ekinin ş'ye dönüşmesi ile keş şeklini almıştır. Eklendiği kelimeye sevgi, şefkat ve sevimlilik ifadesi katar: Täykeş (Nurjekeulı 2016: 243) "Tazabek” özel isimdir (Shaikenova 2020: 92).

Konuşmada sık rastlanan kullanımlardan biri, kişi ismine $+(e)$ ke ekinin eklenerek söylenmesidir. Ekin özelliği, sözcüğe direkt eklenmemesindedir. Sözcügün son bir ya da birkaç hecesi düşürülerek eklenir (Iskakov 159: 1991). Kazak Ana dilinde saygı, şımartmak, sevgi veren ek getirilerek yeni anlamlı isimle hitap edilir. (Januzakov 1971: 113). Ömirali < Ömeke (Nurjekeulı 2016: 34), Jomart < Jomeke (Nurjekeul1 2016: 53), Davletbay < Dävke (Nurjekeul1 2016: 106), Kojabek $<$ Kojeke (Nurjekeulı 2016: 141), Tazabek < Täke (Nurjekeulı 2016: 208). Örneklerden fark edildiği gibi, +(e)ke eki, Kazak Türkçesinde olan ünlü uyumuna uymamaktadır. $\mathrm{Bu}$, dilin gelişme süreciyle ilgili bir istisna olarak belirtilmiştir (Mirzabekov 1999: 123).

+Kan, +An eki de kişi adlarına küçültme, sevgi, şımartma manalarını katar (Janpeyisov vd. 2002: 322). Seyi < Şayken (Nurjekeul1 2016: 162), Kavsar $<$ Kavsen (Nurjekeulı 2016: 262), Tazabek< Tayken (Nurjekeulı 2016: 96). Kazak dilbilimci Sarıbayev, +KAn ekini +han(hen), hon ekleriyle bağdaştırmıştır (2000: 538). Verdiği örneklere göre, Moğolcadaki ek yine küçültme anlamına gelmektedir. 
Jubanov araştırmalarında, Kazakçada sınırlama, kısıtlama, küçültme anlamlarında kullanılan ğana, qana (Eski Türkçede qına, qınya) eklerinin kısalmış şekli $+K A n$ 'ın temelini oluşturmuş olduğunu varsaymıştır. Bota-qan (devenin yavrusu), qoşa-qan (kuzu), buzav-qan (buzağı) örneklerinin yanı sıra, az-ğana (azıcık), kiş-kene (küçücük) gibi örnekleri göstererek fikrini tutarlı bir hale getirmeye çalışmıştır (2010: 441).

Küçültme, şımartma işlevlerini gören ${ }_{+s ̧}$ eki de genelde kişinin ismine eklenerek bu görevleri alır. Bu ek Eski Türkçeden beri var olan bir küçültme ekidir (Gabain 1988: 43, Kononov 1969: 81-88). Fakat romanda bu ek kişi adları ile kaynaşmış olup, Jameş (Nurjekeulı, 2016: 100), Kojaş (Nurjekeulı 2016: 19) şekillerinde özel isimlerde karşımıza çıkmaktadır. Yani, bu şımartma biçimli isimlerin temelinde tam olarak hangi eklerin olduğu belirtilmeden kullanılmaktadır. Bunun dışında, Kitapbek adlı kahramanın Kitaş (Nurjekeulı 2016: 238) olarak zikredilmesi kuralla uyum sağlamaktadır.

Hem Kazak edebi dili hem konuşma dilinde geniş rağbet gören jan, tay gibi unsurlar, kişi adları ya da akrabalık adlarına eklendiğinde duygusal bir anlam katar (Iskakov 159: 1991). Oraljan!" dep erkeletetin äje, "Şäykentay” dep stylaytın ene, "Täykentay” dep mekirenetin ana endi birjola joq. "'Oralcan!' diye torununu şımartan babaanne, şefkatle 'Şaykentay!'diye değer veren kaynana, sevgiyle 'Taykentay!' diyen anne artık yoktu" (Nurjekeulı 2016: 223). Jan ismi, Farsçadaki cân kelimesi gibi gözükmekle birlikte Türkçe olma ihtimali de vardır. Özellikle Kıpçak ve Karluk sahası Türk lehçelerinde özel isimlere ve akrabalık isimlerine getirilerek sevgi, şefkat, yakınlık ifade etme işleviyle kullanımı yaygındır (Shaikenova 2020: 90). Örneğin, Jibekjan (Nurjekeulı 2016: 14), Soptyajan (Nurjekeulı 2016: 52), Kapezjan (Nurjekeulı 2016: 250) gibi kullanımlarda jan'ın kullanımı tıpkı bir isimden isim yapma ekinin kullanımını çağrıştırmaktadır. $\mathrm{Bu}$ unsurun diğer Türk lehçelerindeki kullanımı dikkate alındığında bir isimden isim yapma eki olduğu veya kelime olduğu halde ek özelliği kazandığı görülmektedir.

Abentay (Nurjekeul1 2016: 172), apketay (Nurjekeul1 2016: 31), ajetay (Nurjekeulı 2016: 262), ăgatay (Nurjekeul 12016: 22), apatay (Nurjekeulı 2016: 298) isimlerindeki -tay ise bir isimden isim yapma ekidir. Ek bütün Türk lehçelerinde yaygın veya seyrek olarak küçültme eki işlevinde kullanılmaktadır (Iskakov 1991: 159-160). Ek özel isimlere gelerek sevgi, şefkat ve yakınlık ifade etmektedir.

Bazen aynı işlevdeki eklerin üst üste gelme durumları da olabilir (Iskakov 159: 1991). Romanda da aynı duruma rastlamak mümkündür: Sameştay (Nurjekeulı 2016: 87), Şaykentay (Nurjekeulı 2016: 156), Kavsentay (Nurjekeul 2016: 262), Taykentay (Nurjekeul1 2016: 155).

Romanda bek, bay ile yapılmış isimler orada bulunan kişi adlarının büyük çoğunluğunu oluşturmaktadır. Bek, bay kavramları, Orhun abidelerinde zengin insan manasındadır. Bek, alt boyların başındaki insanlara verilen bir unvan olduğu ve onlar çok büyük miktarda mal sahipleri oldukları belirtilmiştir (Januzakov 1971: 53). Sözcüklerin yapısı konusunda, A.Bernştarm, B.Vladimirtsov gibi bilim adamları, bay<bey<beg şeklindeki gelişmeden bahsederek, sözcüklerin kökenlerinin aynı olma ihtimalini ortaya koymuşlardır (Januzakov 1971: 53). Buna benzer birçok 


\section{Ey, Dünye Ey Romanında Kazaklardaki Lakap Takma, İsim Verme Üzerine...}

fikirler var ve onların hepsi varsayım olarak kalmıştır. Fakat Kazak isimlerine eklenen bay ve bek sözcükleri, insanların inanışlarına dayanarak yüksek bir mevkiye, unvana, varlık içinde yaşamaya ulaşma isteklerini göstermektedir. Böyle bir yapıya sahip olan isimler, romanda başkahramanlardan biri olan Tazabek' in adı başta olmak üzere, birçok buna benzer örnekler bulunmaktadır. Ancak, çoğu isimlerin kahramanları belli başı bir karaktere sahip olmayıp, romanın bazı kısımlarında sadece isimleri geçmektedir: Tazabek (Nurjekeulı 2016: 18), Oralbek (Nurjekeulı 2016: 137), Tavirbek (Nurjekeulı 2016: 222), Kitapbek (Nurjekeulı 2016: 232), Adilbek (Nurjekeul1 2016: 234), Nüsipbek (Nurjekeul1 2016: 91), Äyimbek (Nurjekeulı 2016: 91), Kojabek (Nurjekeulı 2016: 99), Kabılbek (Nurjekeul1 2016: 167), Düysembek (Nurjekeulı 2016: 167), Nurbek (Nurjekeul1 2016: 297), Irayımbek (Nurjekeulı 2016: 116), Kemelbay (Nurjekeulı 2016: 22), Irakımbay (Nurjekeul1 2016: 35), Serikbay (Nurjekeulı 2016: 41), Kelgembay (Nurjekeulı 2016: 91), Turlibay (Nurjekeul1 2016: 100), Amalbay (Nurjekeuli 2016: 119), Şaltabay (Nurjekeulı 2016: 151), J1lq1bay (Nurjekeulı 2016: 166), Ultanbay (246), Dambay (Nurjekeulı 2016: 19), vb.

Koylıbay, Maldıbay, Jilkıbay gibi Kazak adlarında bulunan bay unsurunu Jubanov, Kazakçanın söz dizimiyle (sıfat+isim şeklinde) açıklayıp Koylıbay (koyunlu zengin adam), Maldıbay (mallı zengin adam), Jllkıbay (y1lk11ı zengin adam) şeklinde izah etmiştir. Fakat, Ittbay, Böribay, Edilbay gibi isimlerin anlamını bu çerçevede değerlendirmenin yanlış olacağını da vurgular (2010: 430). Aslında kelimenin ikinci kullanımı dikkate alındığında bay uzantılı isimlerdeki bay kelimesinin zengin anlamındaki bay değil kendisinden önceki kelimenin ünlülerinin kalın olmasından dolayı bey kelimesinin bay şeklini aldı̆̆ı, it, böri ve Edil gibi kelimelerde de analoji yoluyla kalın ünlülü kullanıldığı muhtemeldir. Bu durumda bay kelimesi ile kurulan isimler birer unvan grubudur. İtbay (İt Bey), Böribay (Böri Bey), Edilbay ise (Edil Bey) şeklinde birer unvan grubudur. Diğer isimlerde de bu durum dikkate alınırsa isimler daha anlamlı hale gelecektir.

Genelde Kazaklar, Edilbay gibi bir adı İdil nehri kıyısında dünyaya gelen bir bebeğe vermiş olduğunu dile getirerek, ismin doğulan yere istinaden İdil'de doğan bay (zengin insan) anlamında yorumlamıştır. İtbay, Böribay adlarını ise Kazakların çok eskilere dayandığı totemist görüşlerine bağlayarak, köpekten, kurttan türeyen bay şeklinde açıklamıştır (Jubanov 2010: 430). Romanda bunu çağrıştıran kullanım ve isimler vardır. Karga Türklerde kutsal bir hayvandır. Karga ile ilgili kullanım roman kahramanı kaynanasının gelini Jüzik'e (Nurjekeulı 2016: 119), Tazabek'in annesinin Tazabek'e (Nurjekeulı 2016: 112; 116) Şeyi'nin annesinin (Nurjekeulı 2016: 40) ve kaynanasının Şeyi'ye (Nurjekeulı 2016: 107; 217) “Kargam” diye hitap etmesi, Karga kelimesini sevgi, şefkat, yakınlık ifade etmek için kullanımlarına örnektir. Bunlardan ikincisi bir isimdir. Bu ismin sahibi de karganın mitolojideki kurtarıcı rolünde olan bir kimsedir. Bu durum, Karga'nın Oyratlar'daki "Jangar'ı", "Mancur Kağan'ı", "Vusunların kralı Kunmo'yı" kurtarmasını çağrıştırır (Bogenbayev vd. 2014 : 74). Önce Kazakların çalınan hayvanlarını ardından kaçırılan üç kadını kurtaran Karga adında bir Kalmuktur (Nurjekeulı 2016: 112113). Bu da eserdeki mitoloji ile örtüşen bir isimlendirmedir. 


\section{Akrabalık adları}

Kişilerin gelenek, görenek ve sosyal hiyerarşi gereği gibi değişik sebeplerle bazı kişilerin isimlerini kullanamaması beraberinde onların isimlerinin yerine başka isimleri kullanmayı getirmiştir. Bunun başında ailenin yeni üyesi olan gelinlerin eşinin anne ve babasına veya büyüklerine karşı kullandığı kelimeler gelir. Bu durumun Nurjekeulı'nın eserine de yansıdığını görürüz. Yani akrabalık isimleri de genel Türk kültüründe olduğu gibi Kazaklar arasında da sık sık isimlerin yerine kullanılır. Yazar, eserde genel olarak isim söylenemeyen durumlarda akrabalık adları kullanmıştır, bunlar; apa "anne" (Nurjekeulı 2016: 43), şeşe "anne" (Nurjekeulı 2016: 43), äke "baba" (Nurjekeulı 2016: 43), ağa "ağabey" (Nurjekeulı 2016: 30), ini “erkek kardeş" (Nurjekeulı 2016: 66), äpke "abla” (Nurjekeulı 2016: 78), sinli "kız kardeş" (Nurjekeulı 2016: 203), qarındas "kız kardeş" (Nurjekeulı 2016: 17), jiyen "yeğen" (Nurjekeulı 2016: 216), tate "hala/teyze" (Nurjekeulı 2016: 241), nağaşı "anne tarafi akrabalar" (Nurjekeulı 2016: 250), vb.

Romanda kimi akrabalık adlar dikkat çekicidir. Kazakçada genel olarak kullanılan ake (baba) yerine jakem ifadesinin kullanıldığını görürüz: Apa, Jäkem aman, dedi Ăğntay törge otırıp jatıp (Nurjekeulı 2016: 43) "Anne! Babam sağ salim! dedi yere otururken”. Onı Jäkem aytsın, dedi Kökşegir Davletbayğa burılıp. “Onu Davken anlatsın, dedi Kökşegir Davletbay'a dönüp.” (Nurjekeulı 2016: 111) $\mathrm{Bu}$ örnekte ise kayınbaba yerine jakem kelimesi kullanılmaktadır. Romanda kayınbaba sözcüğünün yerine gelen başka bir ifade bulunmaktadır. Aqırın! Ätyim estydi ğoy. "Yavaş! Babam duyacak!" (Nurjekeulı 2016: 75). Ati sözcüğü kayınbaba anlamında Kuzey ve Doğu Kazakistan' da kullanılan bir kelimedir (KTAS ${ }^{1}, 2005$ : 113).

Bunların dışında Kazakların akrabalık ve dünürlük ilişkilerinde kullanılan basit adlandırmalar da bulunmaktadır. Kudaşa, kördin ğoy, sen üşin bulardan ne estimedim? Jigit tandağanda osı halimdi eskerersiñ. "Eyvah, baldız! Görüyor musun kavga arasında kaldım, senin için bunlardan neler duymadım? Kendine koca seçerken bu halimi unutma!" (Nurjekeulı 2016: 18). Buna benzer jeyge "yenge" (Nurjekeulı 2016: 13), qatın "kadın" (Nurjekeulı 2016: 22), baybişe "çok eşli erkeğin ilk hanımı" (Nurjekeulı 2016: 161), qaynağa "kayın birader" (Nurjekeulı 2016: 54), qaynata "kaynata" (Nurjekeulı 2016: 54), qaynı "kayını" (Nurjekeulı 2016: 96), jezde "enişte" (Nurjekeulı 2016: 144) vb. gibi ifadelerin kişi isminin yerine kullanılması romanda sıkça görülmektedir. Bunlar bazen kişi adlarıyla birlikte gelerek, daha ayrıntılı bir anlatım tarzını oluşturur. Tilevli qudam "Tilevli dünürüm" (Nurjekeulı 2016: 131), Äjiken qudağıyım "Ajiken dünürüm" (Nurjekeulı 2016: 131), Jüzik jẹge "Jüzük yenge" (Nurjekeulı 2016: 80), Tabay jezdem "Tabay eniştem” (Nurjekeul1 2016: 144) vb.

\section{Kazakların ad verme geleneği hakkında}

\footnotetext{
${ }^{1}$ Qazaq Tilinin Aymaqtıq Sözdigi
} 


\section{Ey, Dünye Ey Romanında Kazaklardaki Lakap Takma, İsim Verme Üzerine...}

Telkoja Januzak, Kazakların sosyal ve siyasi hayatını ve değişiklikleri dikkate alarak Kazaklarda kullanılan adları dört dönemi esas alıp dört başlıkta incelemiştir (Januzakov 1971: 27). Bu başlıklardan birincisi; hayvan, doğa ve doğal olayların adlarının isim olarak verildiği Eski Türkler dönemidir (Januzakov 1971: 27). İkincisi Arapça, Farsça ve Moğolca isimlerin yaygınlaştığı X-XVII. Yüzyılları içine alan Orta çağ dönemidir (Januzakov 1971: 36). Üçüncüsü, Jungarlarla savaş ve Rusya'nın hâkimiyeti olan XVII-XIX. Yüzyılları kapsayan dönemdir (Januzakov 1971: 60). Dördüncüsü ise Ekim devrimi ve sonrasını içine alıp etkisi günümüze kadar devam eden dönemdir (Januzakov 1971: 68). Sovyet döneminde yapılmış olan ve Kazaklar arasında kullanılan isimlerin geleneğe nasıl dâhil olduğunun izah edildiği çalışma mevcut isimlerin de tasnifinde dikkate alınabilecek önemli tespitler içermektedir.

Romanda başkahraman Tazabek'in dedelerinden biri olan Alpar aynı zamanda Kazak tarihindeki Şaltabay adlı ozanın babasının da adıdır (Nurjekeulı 2016: 151). Januzak, bu şiirden yola çıkarak Alpar ismini Kül Tigin anıtında yer alan kahraman er anlamındaki Alp Er adı ile ilişkilendirmiştir (2007: 391). Alper Tunga destanında gördügümüz ve Türkiye Türkçesinde de sıkça rastlanan bu isim Kazak Türkçesinde kullanılan eski isimlerden olup, günümüzde çok nadir kullanılmaktadır.

Eski Türk dönemine ait ya da ona özenle yapılan isimlendirmeler çok nadirdir. Ondan sonraki dönemde İslam dininin Türkler arasında yaygınlaşması, onun arkasından Moğolların Türklerle karışımı, yeni bir toplumu meydana getirmiştir. Böyle bir değişiklik insanların bilincini de değiştirmiştir, dolayısı ile yeni kurallara, yeni düşünce tarzına uygun isimler çoğalmıştır. Januzak, bu dönem için Otamiş, Kutluğ (1971: 38); Abu Bakr, Abulfath, İbrahim, Sabit (1971: 38); Şağatay, Batıy, Noyan, Tümenbay (1971: 46) gibi isimlerden örnekler göstermiştir. Romanda da ortaçağ döneminde oluşma ihtimali yüksek olan isimler aşağıda sıralanmıştır: Abdihalıq (Nurjekeulı 2016: 134) Sultanbek, Ävbäkir, Sadıqbek, Äbilğazı, Jaqıpberdi, Şoqpar (Nurjekeul 2016: 19), Aldabergen (Nurjekeulı 2016: 116), Äz Jänibek (Nurjekeulı 2016: 161), Jaqipberdi, Uzaq (Nurjekeulı 2016: 40).

Arapçadan Kazakçaya geçen çoğu kişi adları telaffuz edilmekte zorluklar getirdiği için, Kazaklar kendi diline uygun bir şekilde değişikliklere uğratmıştır, bunlar birbirinden farklı gibi görünse de bütün Türk dünyasında ortak mantıkla konulan isimlerdir. (Januzakov 1971: 38). Ävbäkir < Ebu Bekir, Äbilğazı < Ebü'lGâzî, Aldabergen < Allabergen, Jaqıpberdi < Yakub berdi (Gülensoy 1994: 5-7).

Üçüncü dönemde, XVII-XIX. yüzyıllar arasında Kazaklarla Cungarlar savaş1, Rus Çarlık Hükümetinin sömürgeleştirme siyasetine karşı çıkan ayaklanmalar neticesinde destanlara dönüşen ve Rusçadan geçmiş bazı kişi isimleri sıralanmıştır (Januzakov 1971: 61). Romandan Qangeldi (Nurjekeulı 2016: 116), Savrıq (Nurjekeulı 2016: 40), vb. örnek olarak verilebilir.

Sovyetler Birliğinin kuruluşu, Türkistan halkları için yeni bir devrin başlangıcıdır. Kazak isimlerinin tarihine göre dördüncü dönem olarak kabul edilen bu bölüm, romandaki kişi adlarına da tesir etmiştir. Romanın başkahramanları dünyaya gelen çocuğuna Kenesbek adını vermiştir: Onıı atın el-jurt Keyesbek dep qoydl. "Onun ismini halk Kenesbek koydu." (Nurjekeulı 2016: 254). Yazar, bu 


\section{Hikmet KORAŞ - Gulshat SHAIKENOVA}

sırada toplumundaki düşünce tarzının döneme göre nasıl değiştiğini bir isimlendirme aracılı̆̆gyla göstermiştir.

Romanda aktif halde kullanılmasına rağmen, kısaltılmış şekilde verilen isimlerin anlamı ve etimolojisi hakkında inceleme yapılamamıştır: Samen, Aben (Nurjekeul1 2016: 129); Pişan (Nurjekeulı 2016: 198), Jämeş, Qojaş, Äjiken, vb.

\section{Sonuç}

Edebi eser bir yanıyla toplumun aynası diğer yanıyla yazarın şuuraltı ve hayalleridir. "Ey, Dünye Ey" romanında bunu görülebilir.

Romanda yazarın seçtiği isimlerin çoğu Kazak tarihindeki belli bir görevi yerine getiren ve adı destanlaşan kişilerin isimleridir. Yazar bunları günümüzdeki okuyucu için idealleştirmektedir. Özellikle Kazaklar arasında kullanılmayan ama eserde var olan bazı tarihi isimlerle mitoloji ile izah edilebilen isimlendirmeler yazarın okuyucuya kökenini gösterme ve kimlik inşası için kullandığı unsurlardır.

Eserde dikkat çeken diğer husus verilen isim ve takılan lakaplarla, romanda bahsedilen sosyal hayat okuyucuya köklerini ve geçmişini göstermektedir. Çocukların anne babalarına ile kaynana kayın babalarına ve kendilerinden büyük birinci derece yakınlarına isim kullanmadan akrabalık isimleri ve kendi taktıkları lakaplarla hitap etmeleri, kökleri mitolojiye kadar giden ancak bugün saygı gereği deyip geçilen uygulamalardır.

Siradan bir tarihi roman gibi gözükse de eser özellikle isimlendirme ve lakap takma konusu çerçevesinde değerlendirildiğinde Kazak milli kimliğini inşa etme gayretiyle kaleme alınmış, yeni nesillere atalarının yaşadığı katliamları ve sıkıntıları da hatırlatan geleceğin geçmişi kucaklamakla, kendi değerleri ile yaşamakla mümkün olduğunu gösteren önemli bir eserdir.

\section{KAYNAKÇA}

Aksan, Doğan. (2015). Her Yönüyle Dil Ana Çizgileriyle Dil Bilim. Ankara: TDK. Avezov, Muhtar. (2016). Qlylı Zaman. Almatı: An Arıs Baspasi.

Bacakl1, Y1lmaz. (2019). “Beksultan Nurjekeulı'nın "Ey, Dünya Ey!” Adlı Romanında Kazak Kimliği ve Rus İmajı”. Karadeniz Uluslararası Bilimsel Dergi. 42, 254-274.

Bogenbayev, Nurbolat ve Calmirza, Aydın. (2014). “Eski Türk Dünya Görüşündeki

'Kut'Ve 'Karga' Kavramlarl”. Milli Folklor. Y11 26, Say1 103, 69-79.

Çakır, Emine. (2018) “Toplumsal Bellekte Ad Verme Geleneği ve İdeoloji: Satuk Buğra Han”. Milli Folklor. Sayı 119, 31-47.

Ercilasun, A. -Aliyev, A.K. -Şayhulov, A. -Kajıbek, E.Z. -Konkabayulı, K. -Yusuf, B. -Göklenov, C. -Mahpir, V.U. -Çeçenov, (1991). A. Karşılaştırmalı Türk Lehçeleri Sözlüğ̈̈ C. I. Ankara: Kültür Bakanlığı Yayınları.

Erol Çalışkan, Şerife Seher. (2016). "Türk Folklorunda Lâkap Verme Geleneği: Bartın Örneği”. CBÜ Sosyal Bilimler Dergisi, 14/3. 103-126.

Gabain, A. Von. (1988). Eski Türkçenin Grameri. (çev. M Akalın). Ankara: TDK. Gülensoy, Tuncer. (1994). “Türklerde 'Ad Verme Geleneği've 'Hektor'”. Milli Folklor. Say1 22, 5-7. 


\section{Ey, Dünye Ey Romanında Kazaklardaki Lakap Takma, İsim Verme Üzerine...}

Isqaqov, Ahmedi. (1991). Qazirgi Qazaq Tili. Almatı: Ana Tili Baspası.

İbatov, Ärsen. (1986). "Kisi Attarının Kurılım Jüyesi” Kazak Onomastikasının Maseleleri. Almatı: Ğılım Baspası.

Janpeyisov, E. -Husayın, K. -Jünisbek, A. -Oralbayeva, N. İsayev, S. -Ayğabılulı,

A. -Sirğaliyev, M. -Amir, R. Valiyev, N. (2002). Kazak Grammatikası.

Fonetika, Sözjasam, Morfologiya, Sintaksis. Astana: A.Baytursınov atındağ1

Til Bilimi İnstitüti.

Januzak, Telqoja. (2007). Kazak Onomastikası Atavlar Sirı. Almatı: Dayk-Press.

Januzakov, Telqoja. (1971). Kazak Esimderinin Tarihı. Almatı: Ğılım Baspası.

Jayabekova, A.-Januzaqov, T.-Äbilqasımov, B vd. (2011). Qazaq Ädebi Tiliniך

Sözdigi. C.15. Qazaq Ensiklopediyas1. Almatı: Til Bilimi İnstitutı.

Jubanov, Kudaybergen. (2010). Kazak Tili Jönindegi Zertteuler. Almat1: Atamura.

Kaliyev, B.-Nakısbekov, O.-Sarıbayev, Ş. vd. (2005). Kazak Tilinin Aymaqtıq Sözdigi. Almatı: Arıs Baspası.

Kayasandık, Ahmet. (2019). "Türkçe Kişi Adları Bibliyografyası Denemesi”. Journal of Strategic Research in Social Science, 5/1), 57-90.

Kaydarov, A.-Sizdıkova, R. vd. (1990). Kudaybergen Jubanov jane Kazak Sovet Til

Bilimi Almatı: (Kazak SSR Ğılım Akademyası) A.Baytursınov atındağı Til

Bilimi İnstitut1.

Kononov, Andrey. (1969). "İsimlerin ve Sifatların Küçültme Şekilleri ve Söz

Yapımı”. Türk Dili Araştırmaları Yıllı̆̆ı. Belleten 1968. 16, 81-88.

Mirzabekov, Saparhan. (1999). Kazak Tilinin Dıbıs Jüyesi. Almatı: Sözdik-Slovar.

Nurjekeul1, Beksultan. (2016). Ey, Dünye Ey. Almatı: Jalın.

Oğuz, Şükran ve Oğuz, İsmail. (2008). "Lakap Verme Geleneğinde Manisa İli

Demirci İlçesi Örneği”". 38. ICANAS (Uluslararası Asya ve Kuzey Afrika

Çalışmaları Kongresi) 10-15 Eylül 2007. Ankara/Türkiye: Bildiriler: Din,

I.Cilt. Ankara: Atatürk Dil ve tarih Yüksek Kurumu Yayınları, 1127-1139.

Qaliyev, Bayınqol. (2014). Kazak Tilinin Tüsindirme Sözdigi. Almatı: Memlekettik

Tildi Damıtu Ortalığı.

Sarıbayev, Şora. (2000). Kazak Til Bilimi Maseleleri Voprosi Kazahskogo

Yazıkoznaniya. Almatı: Arıs Baspası.

Shaikenova, Gulshat. (2020). Beksultan Nurjekeulı'nın “Ey, Dünye ey!” Romanı

Üzerine Dil ve Üslup Çalışması. Yayımlanmamış Doktora Tezi. Niğde:

Niğde Ömer Halisdemir Üniversitesi Sosyal Bilimler Enstitüsü.

Türktaş, Mevlüt Metin. (2019). "Türklerde Ad Verme ile Ilgili Bazı Tespitler”. TÜRÜK Uluslararası Dil, Edebiyat ve Halkbilimi Araştırmaları Dergisi. Y11 7, Sayı 17, 34-44. 